\title{
The Discordant Combination of Civil-Law Prosecution System and Presidentialism: A Theoretical Framework
}

\author{
Sun-Woo Lee ${ }^{1}$ \\ ${ }^{1}$ Department of Politics, University of Glasgow, Glasgow, UK \\ Correspondence: Sun-Woo Lee, Department of Politics, University of Glasgow, Glasgow, G12 8QQ, UK. Tel: \\ 44-141-330-8315. E-mail: s.lee.3@research.gla.ac.uk
}

Received: December 9, 2013 Accepted: March 11, 2014 Online Published: May 28, 2014

doi:10.5539/jpl.v7n2p81

URL: http://dx.doi.org/10.5539/jpl.v7n2p81

\begin{abstract}
Civil-law prosecutors could damage particular politicians' moral foundations with their own timing and extent, manipulating criminal proceedings through their broad power within the centralized criminal procedure. This is why they must be cautiously checked by any other body of government, contrary to their common-law counterparts who exercise limited power because of the decentralized criminal procedure. Fortunately, in most civil-law countries, prosecutors are required to be accountable to democratic bodies, despite the global trend of judicial independence. In several new presidential democracies, however, civil-law prosecutors are often involved in the judicialization of politics through criminal proceedings, despite their accountability to a political branch, unlike in the continental European countries. Why is there such a difference? To answer this question, this article provides an innovative theoretical framework explaining that civil-law prosecutors would be induced to abuse their great power in a partisan position, not under a consensus form of government, but under presidentialism, with the new institutionalist approach. According to this framework, empirical researches will also be encouraged.
\end{abstract}

Keywords: common-law prosecution system, civil-law prosecution system, consensus forms of government, presidentialism, the judicialization of politics

\section{Introduction}

Judiciaries have recently attained institutional independence, from the other branches of government, in the administration of members' careers as well as in judicial review of legislation, regardless of legal traditions, all over the world (Tate \& Vallinder, 1995). This tendency of judicial independence globally contributes to the judicialization of politics (the politicization of justice). Thus, among democrats, there is a substantial concern about increasingly unaccountable judiciaries (Ginsburg, 2003; Przeworski, 2010). Especially according to Maravall (2003: 279) and Zannotti (1995: 182-183), a rigid insulation of civil-law judicial officers from elected politicians could intensify the danger of the judicialization of politics, given the absence of institutional elements of a common-law system which prevent judges and prosecutors, from making partisan decisions, to a certain extent. Even in some developed democracies with the civil-law tradition, such as Italy and France, judicial officers obtaining more independence from the political branches than previously began to come into conflict with democratic processes (Guarnieri, 2003). Above all, civil-law prosecutors unaccountable to any electoral branch can seriously pervert democratic processes, unlike common-law counterparts, although the political role of prosecutors has rarely received attention. Indeed, they have damaged particular politicians' moral foundations by manipulating criminal proceedings with their own timing and extent, via their wide discretionary power over pre-trial criminal procedures (Di Federico, 1995; 1998). In this way, it seems undoubtedly fortunate that prosecutors are still controlled by the executive leadership and are correspondingly required to be accountable to democratic bodies in most civil-law countries.

Here, a neglected but critical question should be raised. Can civil-law prosecutors, if accountable to electoral branches, always be induced to observe political neutrality? Obviously, a quarrel over prosecutors' partisan behavior has seldom arisen in the continental European countries which have a civil-law system and a consensus form of government such as the parliamentary or dual executive system. By contrast, in several new democracies where presidentialism is combined with a civil-law system, prosecutors often manipulate criminal proceedings against particular politicians, for partisan ends, despite their strong accountability to an elected body. In these 
new democracies, as liberal critics point out, prosecutors frequently serve as a political weapon only in favor of an incumbent president. However, a more interesting point is that they sometimes go against the president, especially in the last phase of his tenure. For example, Russian President Boris Yeltsin, Peruvian President Alberto Fujimori, Taiwan President Chen Shui-bian, and South Korean President Yong-sam Kim and Dae-jung Kim had once dominated and made use of the prosecutor's office, but could not escape this miserable fate. If so, why has this pattern of the politicization of prosecutors repeatedly happened in the new presidential democracies with a civil-law tradition? As a scholarly contribution, this paper provides an innovative theoretical framework to answer this question, with the perspective of new institutionalism, and also encourages further empirical research.

This article is structured as follows. First, I briefly review the multifaceted relationship between the rule of law and democracy, focusing on the issue of judicial independence and accountability, and identify why civil-law prosecutors should be considered major actors in the judicialization of politics. Secondly, I draw a comparison between common-law and civil-law prosecution systems. This section concentrates on how each institutional arrangement can ensure a balance between the rule of law and democracy by inducing prosecutors to remain impartial in criminal proceedings, particularly against major politicians. Thirdly, I explain why a civil-law prosecution system should necessarily be combined with a consensus form of government to preserve the balance between the rule of law and democracy, as in the continental European countries. Fourthly, I explain why an institutional disharmony would result from the combination of a civil-law prosecution system and presidentialism, as in some emerging democracies. Finally, I present a conclusion of the academic implications as well as practical suggestions.

\section{The Judicialization of Politics, and the 'Rule of Law as a Political Weapon'}

Historically, the rule of law developed from growing control over monarchs through the constitution. It has its origins in modern liberalism, protecting individual property rights from monarchs, especially for the bourgeoisie. As a result of the Glorious Revolution in England, for example, the rule of law began to restrict the monarch's arbitrary decision over rules and tax rates, limiting his legislative and judicial powers (North \& Weingast, 1989). Afterward, as elections with mass participation and competition among multiple candidates were enacted with the consecutive waves of democratization, elected politicians replaced the monarchs. However, regular elections can impose vertical accountability on the elected rulers but seldom make them horizontally accountable to the rule of law.

If a majoritarian government is not constrained by the constitution determining what it can and cannot do, it may violate political rights and civil liberties during inter-elections (Rose, 2009: 12-15). Beyond merely making unconstitutional decisions regarding policy or mega-politics issues, a political faction that dominates the executive can nefariously pervert numerous kinds of democratic process (even national elections), through illegal administrative maneuvers. Consequently, a judicature that has independence from the other branches of government is considered one of the most effective ways to guarantee the rule of law in the context of democracy. This is founded on the belief that only the insulated courts from the political branches are capable of protecting not just political oppositions, but also every citizen including all minorities, from the arbitrary decisions of a political majority. Hence, several countries have increasingly permitted judicial officers to manage their career for themselves in a judicial council, and correspondingly made them no longer accountable to political authorities.

On the other hand, some scholars concentrate on a few political conditions which enable judges to behave independently, rather than on the institutional arrangement exempting them from accountability to electoral branches. For instance, Caldeira (1986) and Vanberg (2001) argued that the more public support a judiciary enjoys, the more autonomous decisions it can issue. Also, others proposed that a judiciary can make relatively independent decisions under a political polarization or divided government (Barzilai, 1997; Chavez, Ferejohn \& Weingast, 2003). Yet these arguments could be built only on the precondition of a judiciary somewhat insulated from any other branch of government (Helmke, 2002: 301). It cannot be denied that judicial officers would hardly have an incentive to challenge the chief executive, when their career and fate are ultimately dependent on the executive branch (Olson, 2000: 35).

However, independence from political authorities is never a value in itself, but merely one of the means to achieve judicial fairness (Shapiro, 1981). Individuals and groups could be often tempted to politically use independent judicial officers, and consequently politics could be judicialized. Given that there is an essential tension between the rule of law and democracy (Ferejohn \& Pasquino, 2003: 243; Habermas, 2001; Sejersted, 1988), the judicialization of politics cannot be totally avoided. However, independent but biased judges may 
issue partisan decisions, along with the judicialization of politics. Unless a judiciary is autonomous not only from a political majority but also from any interested sides, it cannot be acknowledged as a truly independent body (Kornhauser, 2002: 49). Such an ideal notion of complete independence, nonetheless, is impossible to accomplish (Russell, 2001: 11-12). Since any judicial decision cannot be issued automatically by laws per se, but only through the interpretation and application of judicial officers, it inevitably contains more or less subjective interests. Even worse, independent judicial officers can unfairly apply laws to take their own benefits. The question of who watches the watchmen is raised. For instance, they could attempt to make an alliance with a particular political faction, in order to maximize their prerogatives, or with a particular business, in order to take unjust pecuniary rewards (Bancaud \& Boigeol, 1995; della Porta, 2001; O'Donnell, 2004). As a result, democratic processes would be distorted to a considerable extent.

The recent expansion of judicial review also has a similar (but more directly policy-related) effect on democracy with judicial independence from the other branches of government (Ferejohn \& Pasquino, 2003; Stone Sweet, 2000). According to Hirschl (2000; 2004), for instance, the global trend of strengthened judicial review could reinforce hegemonic capitalists on the basis of neoliberalism while hardly contributing to expansion of the progressive rights for distributive justice. Although it is hard to distinguish between a tyrannical majoritarian government - discriminating minorities either procedurally or substantively - and a non-tyrannical one, judicial review can get improperly politicized, bringing a 'countermajoritarian difficulty' against clearly legitimate decisions of a political majority (Bickel, 1986). The judiciary may be expected to make itself behave fairly in order to secure public trust, but it will do so at best in a long-term perspective. Therefore, some additional institutions must be adopted before insulating judicial officers from electoral branches or allowing them judicial review, otherwise democratic accountability must be imposed on them to some degree, in order to preserve a balance between the rule of law and democracy.

On the other hand, some literatures suggest the 'rule of law as a political weapon' as a new pattern of the judicialization of politics (Guarnieri, 2003; Maravall, 2003). This is distinguished from mere judicial activism by which courts make an ultimate decision in policy-making processes. Instead, independent but partisan judges or prosecutors could be misused, by their political patron, to fabricate criminal proceedings in order to stigmatize his political enemies as immoral or criminal suspects (Maravall, 2003: 262). In other words, judicial officers can serve as an instrument for a particular political faction to distort democratic processes for its own advantage through, namely, the politicization of criminal justice.

In particular, it is required to pay more attention to prosecutors than judges as major actors in this pattern of the judicialization of politics. Although judges have obtained more independence from the political branches with the global trend, they seldom have the initiative to manipulate criminal proceedings, since they can issue no decision without prosecutors' indictment. Judges can influence politicians only passively, when such an opportunity becomes available (Ginsburg, 2008: 71). They might also play a critical role in undermining a particular politician's moral foundations, occasionally leading him to defeat, but whether the politician under suspicion is granted an acquittal from the courts in the future would not be very meaningful in many cases. By contrast, prosecutors take charge of indictments, and exercise the initiative to stigmatize targeted politicians as criminal suspects. Thus, when unaccountable to any bodies of government, the prosecutors can often seek their own partisan goals, regardless of judges' final decision, through their power of preemptive action.

Nonetheless, on the one hand, in common-law countries, prosecutors have not displayed overly partisan behavior in criminal proceedings, though they enjoy a fairly insulated position from electoral branches and are therefore frequently involved in the judicialization of politics. In most civil-law countries, on the other hand, prosecutors are still hierarchically accountable to the other branches of government, especially the executive leadership, in contrary to scholarly concerns. Among the legal countries, there are few cases, such as Italy, in which prosecutors enjoy institutional security from elected politicians (Di Federico, 1995). However, in several new democracies where presidentialism is combined with a civil-law prosecution system, prosecutors have often taken partisan action, despite their indirect democratic accountability.

The next section compares the institutional arrangements of common-law and civil-law prosecution systems, which have carefully preserved a balance between the rule of law and democracy by ensuring the fairness of criminal proceedings in their own way. Should this institutional difference be clarified first, it could also explain why civil-law prosecutors are often induced to display partisan behavior in criminal proceedings against major politicians under a presidential system, but not under a consensus form of government. 


\section{Two Types of Prosecution Systems and Balances between the Rule of Law and Democracy}

\subsection{The Institutional Equilibrium of a Common-Law Prosecution System}

A common-law system has allowed individual judicial officers to enjoy an equal constitutional status with political authorities by granting more independence from the other branches of government, reliant on the philosophy of liberalism, rather than a civil-law system. Their insulated position is institutionalized through the judicial career system of this legal tradition (Kirchheimer, 1961: 108). Most common-law judicial officers are selected, among prestigious lawyers, by the judicial branch itself, and no longer strongly affected by politicians' external influence as well as their superiors' regular evaluation within the bureaucratic career ladder. Although electoral branches intervene in the appointments of the high court judges and senior prosecutors, these processes can be understood to function as mere a priori verification on the candidates' professional qualification and ideological inclination rather than as persistent political check over the judicial bodies. In this respect, federal judges are even granted a life-tenure job in typical common-law countries, such as the US and Canada. The consistency of judgments or indictments has also been preserved by continuously accumulated precedents, rather than by the discipline of hierarchy in the judiciary or public prosecution (Mattei \& Pes, 2008: 269). In the US, moreover, judges and prosecutors in many states are directly accountable to citizens, as they have to win popular votes. These judicial elections can ironically permit them to secure the highest level of independence from other branches of government.

Such thorough insularity is undoubtedly to save their autonomy to the degree where any exogenous influence - a particular political or business power - cannot easily buy them off (Larkins, 1996: 608). This institutional arrangement, albeit not always successful, has helped the judicature to prevent the tyranny of a majoritarian government, and largely maintained the rule of law in common-law countries. Especially in the US, the independent judiciary has obliged both the executive and legislative branches to be horizontally accountable to the constitutional principle. On the other side, however, it can be argued that a common-law system seldom requires the judiciary to be accountable to democratic bodies, which therefore could potentially increase judicial activism. That is, more and more political or social groups have been motivated not to mobilize mass supports but to rely on the judicial bodies, for defeating their opposition, and consequently politics cannot help being frequently judicialized in common-law countries, particularly in the US (Crenson \& Ginsberg, 2004). In this context, Epp (1998) identified the 'support structure for legal mobilization', including rights advocacy lawyers, rights advocacy organizations, and sources of funding for litigation, as a crucial additional factor which contributes to the expansion of the judicialization of politics in the US, Canada, and the UK.

However, it is notable that common-law judicial officers can exercise narrower jurisdictions than civil-law ones. First, under an adversarial system, adopted by most common-law countries, judges' position cannot overwhelm both sides, and the prosecutors' role is also restricted to one of the two in trials (Reichel, 2005: 166-169). Moreover, common-law judges and prosecutors cannot monopolize the interpretation of laws in issuing judgments and indictments, because they have to share the authorities of legal decisions with petty and grand juries, respectively (Friedman, 1973: 134-137). In addition, their legal decisions can be less arbitrary than civil-law counterparts', since they must follow the precedents in applying laws - albeit not in the early period when quantities of precedents were produced (Gargarella, 2003: 186).

In common-law countries, above all, prosecutors' power is significantly limited, because of the decentralized structure of the criminal justice system (Hamilton, 2008; Kyprianou, 2008). The prosecutors are usually checked by the investigators of various law enforcement agencies, including police officers, who chiefly control the investigative process on pre-trial stages. In most common-law countries, such as the US, Canada and England, prosecutors generally do not hold the rights to open and close criminal cases at their disposal, or the power to direct the police officers during investigations. They can just declare either the indictment or non-indictment on pre-examined cases in the principle of discretionary indictment system, and even the right to charge criminal suspects must be shared with the grand juries. That is, in common-law countries, 'checks and balances' can be introduced between the prosecution and investigation, and therefore prosecutors are systematically enforced to observe due process for human rights by indicting criminal suspects as fairly as possible.

Therefore, this institutional arrangement of common-law prosecution systems also has a significant implication, concerning the politicization of criminal justice. In common-law countries, many individuals and groups, including politicians themselves, may attempt to use criminal proceedings politically, given the relatively higher independence of judicial officers, but nobody can easily stigmatize his political enemies as criminal suspects, because he must make alliances with both the prosecutorial and investigatory agencies, and even buy off the grand juries, in order to manipulate the criminal proceedings. Furthermore, the decentralized criminal justice 
system can protect information on the progress of investigations from a leak, and accordingly the media cannot recklessly report on politicians who are merely suspected. The presumption of innocence would then not be seriously damaged. In the US, only special prosecutors can exercise both the powers to investigate and indict major politicians under suspicion, but even the criminal proceedings are unlikely to be seriously distorted because such high-profile criminal cases are rare and attract national interest. Hence, even an incumbent president cannot easily distort democratic processes through the political manipulation of criminal proceedings. In common-law countries, the judicialization of politics arose as an obvious problem, given that politicians have increasingly relied upon criminal proceedings against their political opponents. Nonetheless, the danger of breaking the balance between the rule of law and democracy can be minimized, due to the self-regulating institutional configuration of a common-law criminal justice system.

\subsection{The Institutional Equilibrium of a Civil-Law Prosecution System}

In traditional civil-law countries, the position of the judiciary was rather subordinate to the political authorities from the era of monarchy (Merryman, 1985). Therefore, the view that judicial officers must only be faithful servants for parliamentary sovereignty has been dominant, since monarchism was replaced with democracy. Accordingly, a bureaucratic hierarchy was also developed to control judicial officers in the civil-law tradition. Specifically, higher-ranking judges and prosecutors influence lower rankers' careers - with recruiting, disciplinary proceedings, transfers, and promotion to upper ranks in particular - via their regular assessments, while political leadership plays a decisive role in selecting the top rankers, such as supreme justices or the prosecutor general (Ehrmann, 1976: 76-78; Guarnieri, 2003: 225-226; Shapiro, 1981: 32). Since the salary, prestige and personal power of individual judges and prosecutors can be improved mostly through their career advancement in such a pyramid-like organizational setup, this institutional configuration, based on the typical 'principal-agent model', enables electoral branches to supervise judicial officers vertically, and further make them accountable to citizens indirectly.

In most civil-law countries, as noted above, prosecutors are still controlled through this traditional institutional mechanism, though judges have increasingly attained institutional security from the political branches. This seems reasonable, given that civil-law prosecutors can be transformed into a political weapon due to the centralized structure of criminal procedure in an inquisitorial system, unless they are properly curbed. Civil-law prosecutors can exercise broad power throughout every pre-trial stage of criminal procedures, as they hold the right not only to control the investigation of criminal cases, but also to indict the suspects (Di Federico, 1998; Kyprianou, 2008). There are in fact some supplementary institutions that contribute to checking the prosecutors' extensive power in part. For example, in Germany and Italy, the prosecution service adopts the mandatory indictment system, in which a prosecutor must charge criminal suspects unconditionally when the necessary conditions are presented during the investigation. In France, prosecutors exceptionally hold both the powers to investigate and indict criminal suspects as well as the discretionary indictment system, but they are essentially required to transfer their investigative power to the instructing judges in high-profile criminal cases (Guarnieri, 2003: 234). The broadness of the prosecutors' power varies, depending on how closely they can dominate investigators during criminal investigations, in civil-law countries, but they can largely intervene at any point from the investigation to indictment, and correspondingly manipulate criminal proceedings at their discretion.

The civil-law prosecutors' centralized power can raise the efficiency of criminal proceedings and further contribute to public order. However, such extensive power can be intentionally misused to stigmatize any innocent person as a criminal suspect or to give immunity to an offender. Hence, civil-law prosecutors could more frequently damage human rights than common-law prosecutors, when gaining an exemption of accountability, like in Italy. In particular, the prosecutors can undermine competitive democratic processes by manipulating criminal proceedings involving a political faction whom they do not support (Di Federico, 1995: 239). Then, vigorous competition among the media to get a scoop on political scandals can also empower their political influence (Jiménez, 1998). On the one side, civil-law prosecutors can use the press to form negative public opinion toward the suspected politicians through the leak of information without any constraint. On the other side, the press can recklessly report on politicians under investigation, assuming that the prosecutors will eventually indict them. The presumption of innocence cannot help being seriously compromised. Therefore, if civil-law prosecutors distort criminal justice in such a political way, immediately before an election, the targeted political faction will be disadvantaged in the contest. Even though the politicians receive a verdict of non-guilty after the election, they will be unable to recover from the political defeat for a while.

On this account, in most civil-law countries, prosecutors are still required to exercise their great power, only based on their accountability to democratic bodies. Because of their weaker position compared to the political authorities, it can be deemed that they may fail in their original obligation to keep political majorities from ruling 
tyrannically. However, this does not mean that the prosecutors would be as inactive to the extent that they cannot punish politicians after committing a crime. Rather, if civil-law prosecutors are controlled by a suprapartisan influence, they can be forced to refrain themselves from wielding their vast power in a partisan manner, and correspondingly to manage criminal proceedings against suspected politicians as cautiously and impartially as possible. Then, every political faction can humbly accept prosecutors' decisions without doubts about their partisan bias, and consequently the political majority can also be restrained from ruling tyrannically. In this way, a civil-law prosecution system maintains the balance between the rule of law and democracy. Therefore, the critical point is how the suprapartisan control over civil-law prosecutors is generated, which depends on the form of government.

\section{Institutional Harmony between a Civil-Law Prosecution System and Consensus Form of Government: Old European Democracies}

Clearly, the institutional configuration of a civil-law system provides a strong incentive to individual judicial officers to work hard, and at the same time, to exercise their great power necessarily based on their accountability. However, this requires one more condition, which is that top-ranking judicial officers should be motivated to be responsible to as many different political forces as possible, and not to be loyal to a particular faction. Interestingly, this implies that in civil-law countries, the rule of law is more likely to settle down with a consensus democracy than a majoritarian one, and with a parliamentary democracy than a presidential one. As discussed above, unless civil-law prosecutors, who can arbitrarily stigmatize any politician as a criminal suspect, are restrained from holding a partisan position by the suprapartisan pressure under a consensus democracy, they may transform themselves into a dangerous instrument, and consequently fail to deliver their official duty curbing tyrannical political majorities.

Under consensual parliamentarism, first of all, the prime minister usually has to respect the collegial decision-making process, and share ministerial posts with other parties, let alone other leaders of the ruling party (Linz, 1994: 31-32). Likewise, a suprapartisan coalition - even embracing the left and the right together - is required for appointing top-ranking judicial officers, even though the judges have recently obtained more independence from the parliament than previously. In Austria, Germany, and the Netherlands, for instance, the highest judicial posts have been occupied by relatively depoliticized figures, as the parliament's suprapartisan approval is invoked when elevating the candidates (Cole, 1959: 969). With this priori control over civil-law judicial officers, a posteriori check on them could also be taken to a certain extent, because a coalition among various political factions has been relatively easily formed. Actually, in these consensus democracies, the judiciary has seldom ruled against parliamentary sovereignty, if not necessarily required, owing to the concern that the suprapartisan majority of a coalition government might overturn its judgments (Ferejohn, Rosenbluth \& Shipan, 2007: 738-739).

The political manipulation of criminal justice by civil-law prosecutors could also be prevented by the suprapartisan pressure from a coalition government, because top-ranking prosecutors have less incentive to form an alliance with a particular political faction, and correspondingly initiate and manage criminal proceedings as impartially as possible. Even if the prosecutor general, who has no more incentive to gain career promotion, might hold a partisan position, other high-ranking prosecutors, who still aim to get advanced to an upper rank or the next prosecutor general, would not follow him but preserve their political neutrality. Thus, the prosecutor general who predicts his inferiors' strategic choice would also give up making a partisan decision. Because of the strict hierarchy where the impartial leaders are at top, the prosecutor's office as a whole is unlikely to hold a partisan bias in thrall to any particular interest, while some individual prosecutors may abuse their broad power for rent-seeking.

In consensual parliamentarism, moreover, the official tenure of government is not fixed but flexible - although this feature brings both positive and negative political effects -, because the composition of executive leadership would change when an assembly dissolves, regardless of regular elections, or when a shift of power occurs within a coalition government (Linz, 1994: 9; Strøm, 2000: 274). If the executive leadership holding ultimate control over judicial careers is unpredictably replaced, judicial officers cannot attempt to get promoted to upper ranks by demonstrating loyalty to a particular political faction with certainty. In this context, Ferejohn, Rosenbluth and Shipan (2007: 746) indicate that, under this form of government, the constitutional courts could review the constitutionality of legislation free from partisan pressure, immediately after a national election, since they could not exactly predict which parties or factions would form the new coalition government. But, in fact, the judicial officers would be consistently induced to apply laws in a depoliticized manner, as the consensual parliamentary government has this ex ante uncertainty as a constant rather than just after elections. If so, civil-law prosecutors, who belong more directly to the changeable executive leadership than the judges, can also 
be induced not simply to be independent but impartial, and consequently cannot dare manipulate criminal proceedings via their far-reaching power, especially against particular politicians.

Also in countries with a dual executive system, such as France, where an incumbent president and premier often share the executive leadership, multiple factions can be enforced to consensually manage the branch - albeit less permanent than under consensual parliamentarism (Blondel, 1992). Therefore, civil-law prosecutors could be motivated to exercise their extensive power relatively fairly, as a particular political faction can hardly seize an exclusive control over their careers, except in such cases in which a president belongs to the majority party and holds command over the party, like in France under President Charles de Gaulle. In addition, in this government form, prosecutors would have difficulty in pursuing career development by devoting loyalty to a particular party or faction, owing to the unpredictable variability over which political factions would share the initiative to compose the executive because of the different timing of presidential and parliamentary elections. In France, the 'powerful' instructing judges, who enjoy more independence from electoral branches than the prosecutors, have sometimes been criticized for their partisan behavior in high-profile criminal cases, but the cases handled by them are actually rare (Verrest, 2000: 215).

Even in the Westminster model, a political faction's exclusive domination over the executive branch can be avoided, given that the prime minister not only has to cooperate with other leaders within the ruling party in composing and managing the cabinet, but also cannot totally ignore the practice of consensus among different parties within the parliament (Dahl, 1989: 157). This is why political affairs such as 'Watergate' seldom occur in countries with any form of parliamentarism (Lijphart, 1992: 14-15). Hence, the prime minister's faction could not easily monopolize the prosecution service as well, although the majority of countries with the Westminster model are adopting a common-law system in which prosecutors' power is substantially limited. Moreover, the Westminster model is not so different from the other consensus forms of government, in the respect that it also brings about the irregular changes within the cabinet members including the prime minister himself. The composition of the Japanese cabinet, for example, has perpetually been reshuffled, even under the long Liberal Democratic Party regime.

In short, the institutional factors of consensus forms of government have induced civil-law prosecutors to exercise their extensive power impartially, rather than to display partisan behavior based on their loyalty to particular politicians. According to the World Justice Project (2013), as expected, the political manipulation of criminal proceedings occurs relatively infrequently, despite the civil-law prosecution system, not only in old consensus democracies, but even in the new ones such as the Czech Republic or Poland. By contrast, why do civil-law prosecutors frequently abandon their political impartiality, and abuse their far-reaching power for a particular political faction, in new presidential democracies? The next section explains this dilemma resulting from the discordant combination of a civil-law prosecution system and presidentialism.

\section{Institutional Disharmony between a Civil-Law Prosecution System and Presidentialism: New Democracies}

The judicialization of politics through criminal proceedings is no more frequent in the continental European countries than in common-law countries, which proves that civil-law prosecutors' extensive power per se would not automatically cause their partisan behaviors, if they are appropriately controlled. Rather, the reason why the prosecutors cannot help being often associated with the perilous politicization of criminal justice can be explained from the institutional disharmony between a civil-law prosecution system and presidentialism.

Along with the Third Wave of democratization, many new democracies adopted a presidential system, which gave the president almost exclusive authority over the formation and management of the executive branch (Carey, 2005: 95-97). Even in this pure presidential system, the legislature can exert a priori and a posteriori influence on the composition of the executive branch to some degree. At times, the legislature retains the right to approve candidates for ministerial-level posts, and occasionally rejects the nominations. In most cases, nonetheless, the president can repeatedly nominate figures whom he prefers, and the threshold of rejection imposed on the legislature is also high. Moreover, ministers and other prominent executive appointees answer only to the president in most presidential systems (Shugart \& Carey, 1992: 106-111). Thus, the presidential power to dominate the executive, including law enforcement agencies, is neither significantly restricted ex ante nor ex post, even under a divided government. More importantly, even senior bureaucrats, including prosecutors, who ought to hold no partisan bias, have been politicized because of the custom in which the president often selects his ministers from the bureaucratic career ladder, in some new democracies (Kang, 2001).

On the other hand, some of these countries inherited a civil-law system as well, from previous undemocratic regimes. In the new democracies, such as South Korea and Russia, the prosecutor's office retained greater power 
and stronger hierarchy than in any other traditional civil-law countries. This is in part because the authoritarian and communist regimes had preferred an extreme type of civil-law prosecution system, to use the prosecutors' enormous power effectively and exclusively (Chen, 2004: 432-438; Lee, 2007; Magaloni, 2008: 190-191). However, even since democratization, an incumbent president can exclusively dominate the prosecution service through his ultimate control over the prosecutors' careers. Indeed, a discordant combination was made as the civil-law prosecution system was combined with presidentialism, and the institutional imbalance has been reproduced. This institutional peril might be a more precarious problem against politically fair criminal proceedings than the prosecutors themselves who served under the past undemocratic regimes, considering that the renewal of personnel is not greatly helpful.

Specifically, the discordant institutional combination forms a political incentive structure for civil-law prosecutors to demonstrate loyalty only toward an incumbent president, as long as he wishes to abuse their enormous power in favor of himself. High-ranking prosecutors, who have less incentive to get promoted to the upper ranks, may be predicted to remain politically impartial and even to investigate or indict the president's circle occasionally. In some countries, to bring this into effect, the constitution fixes the legal tenure of the prosecutor general. However, most of the high-ranking prosecutors, including even the prosecutor general, are likely to maintain their loyalty with the expectation that they will obtain other high executive posts, such as the minister of justice, or at least sustain their current position, if the president has a long remaining period in his official tenure. Also under presidentialism, some civil-law prosecutors may individually seek corrupt rents, via their far-reaching power. Yet it is impossible that the prosecutor's office as a whole is bought off by other political or economic authorities than the current president, because of the strong organizational hierarchy among civil-law prosecutors. The real problem is that a presidential system induces civil-law prosecutors to devote loyalty to the president, in contrast to a consensus form of government which induces the equivalents to maintain political neutrality.

In particular, the 'winner-takes-all' character of presidentialism can make aggressive opposition against the incumbent president a constant, intensifying political polarization (Linz, 1994: 19; Sartori, 1994: 108-109). The possibility of an emergence of divided government would also become high, when a multiparty system is constructed (Mainwaring, 1993), or the time difference between presidential and legislative elections is long (Shugart, 1995). Thus, a political impasse between the two democratic bodies cannot easily be resolved, because one branch is unable to threaten another's survival during a defined period (Stepan \& Skach, 1993: 17-18). Then, an interesting point is that such a violent political conflict, brought by the zero-sum feature of presidentialism, can make both a president and his opponents vulnerable to the judicialization of politics through criminal proceedings. A political faction's loss of moral legitimacy, when it is involved in criminal cases, would be most advantageous to another faction in the political polarization. However, under the discordant combination of the civil-law prosecution system and presidentialism, the president can possess an absolute priority in abusing prosecutors' great power for stigmatizing his political enemies as criminals, even in a divided government. This one-sided politicization of criminal justice not only directly creates a political situation beneficial for the president, distorting democratic processes such as national elections, but also indirectly constructs a social norm tremendously favorable for him. For example, Russian President Vladimir Putin selectively destroyed his political enemies and propagated 'statism', on the pretext of the rule of law, relying on the civil-law prosecution system (Kvurt, 2007; Lee, 2010).

Apart from the offensive value gained from the alliance with civil-law prosecutors, an incumbent president can enjoy the alliance in the aspect of defense as well. In several new democracies, where large-scale privatization has been undertaken as a part of economic reform or the government still intervenes in the distribution of financial resources, the quarrels over corrupt links between politics and businesses are unceasing. This is attributed to the fact that the executive leadership and senior bureaucrats have a decisive influence on the distribution of national socioeconomic resources (Kaufmann \& Siegelbaum, 1997). Hence, it seems natural that not only a president, who possesses the ultimate power to manage the executive, but also his family or close allies could be deeply involved in the corruption (Fish, 2000: 189; Weyland, 1998: 115). However, the president's faction involved in corruption can be given immunity, avoiding sharp political scandals, because civil-law prosecutors are able not only to selectively initiate criminal proceedings, but also to freely terminate the cases without the indictment of suspects, even if any of the cases are already open. A Nobel Peace Prize winner, South Korean President Dae-jung Kim was also criticized for elevating his loyalists to top-ranking prosecutors through his exclusive control over their career, even in the divided government, in order to give immunity to the corruption of his circle members (Cho, 2010: 98-107).

Nonetheless, even an incumbent president cannot dominate civil-law prosecutors at the last period of his tenure. 
The prosecutors would have less incentive to demonstrate loyalty to the president, as he could no longer exert control over their careers. Even if a candidate of the ruling party may have the most potential of taking the next presidency, the continuity between governments is much weaker in presidential systems than in parliamentary ones, and the president often has difficulty in cooperating even with the ruling party when their term is ending (Valenzuela, 1993: 10). It is also uncommon for a retired president to exercise any political leverage. Thus, most of the senior prosecutors, who have accumulated enough career capital to gain top-ranking positions in the next government, would devote no more loyalty to the outgoing president, similar to other high political appointees or top-ranking judges (Grossman, Kumar \& Rourke, 2000: 229-230; Helmke, 2002). Instead, they would pretend to be politically neutral, or change their patron to a leading candidate in order to maximize the chance of their job under the next presidency. At any rate, it must not be an irrational choice for civil-law prosecutors to advertise their morality and capability by actively going against the declining president. The low and middle rankers who are routinely under their partisan superiors' assessment would also deviate from the president, either intentionally or unintentionally.

For example, in South Korea, prosecutors indicted the sons of President Young-sam Kim and Dae-jung Kim with their own perfect timing, even though they had demonstrated loyalty to the presidents during most of their tenure. Thus, Dae-jung Kim sharply criticized, 'Currently the worst cancer in South Korea is the Prosecution Service, which is excessively subservient to an incumbent president during his heyday but violently bites him at the last part of his tenure' (Kim, 2011: 565). Also in Peru, prosecutors quickly targeted President Fujimori immediately after the authoritarian leader's resignation became obvious. In Russia, likewise, prosecutors had willfully covered up the corruption of President Yeltsin and his close allies, but finally instituted criminal proceedings against them during his last phase (Holmes, 1999: 78). Unusually, Russian President Putin managed to avoid the prosecutors' defection to the end. However, this was attributed to the unique political circumstance, in which Putin had not only succeeded in reform to curtail the civil-law prosecutors' enormous power, but had also been appointed as the new prime minister of the next government, before resigning from the presidency, under the electoral authoritarian regime. This case could rather justify this theoretical framework in comparative perspective.

The rapid increases in prosecutors' investigation and indictment against an incumbent president's faction at his last phase is also because at this juncture more and more 'deep throats' begin informing the prosecution service of scandals involving the faction members. However, their behavior can be understood in the same context of the prosecutors' defection against the outgoing president. Moreover, a considerable number of the 'deep throats' may well be working in the prosecutor's office itself. Therefore, this explanation does not run counter to this theoretical framework. Eventually, the president cannot easily avoid the 'lame duck' season intensified by the prosecutors, and he might suffer at their hands even after his official retirement. In sum, an incumbent president can monopolize civil-law prosecutors' extensive power, but the presidential control over their careers may finally backfire and destroy him.

\section{Conclusion}

Independent judicial officers may go against the will of political majorities, even of a non-tyrannical one. Especially, civil-law judicial officers who have recently gained an exemption of accountability to electoral branches are problematic, and the prosecutors, among them, could often intensify the risk of the judicialization of politics through the manipulation of criminal proceedings against major politicians. Thus, it is fortunate that prosecutors still remain accountable to democratic bodies, unlike judges, in most civil-law countries. Nonetheless, there underlies a critical problem that has hitherto never been focused on. Among civil-law countries, adopting either presidentialism or a consensus form of government can make an important difference in inducing prosecutors to refrain from fabricating criminal proceedings politically, despite the common ground that the prosecutor's office is controlled by the executive leadership. Democratic processes have been seriously distorted in several presidential countries, even after democratization, as civil-law prosecutors abuse their extensive power for partisan motives, either for an incumbent president or against him. This article aimed to provide an innovative theoretical framework to answer why the perilous politicization of criminal justice happens under the institutional combination of presidentialism and a civil-law prosecution system, with the perspective of new institutionalism. Therefore, empirical research can also be encouraged in accordance with the theoretical framework.

If emerging democracies introduce presidentialism without careful consideration of whether their prosecution system is closer to common-law or civil-law tradition, this hasty choice will upset a subtle balance between the rule of law and democracy, and consequently impede democratic consolidation. Since quite a number of new democracies have already made this mistake, prosecutors have taken partisan attitudes, along with presidential 
electoral cycles, and the presidents have oscillated between an 'imperial' and 'lame duck' ruler. Like civil-law prosecutors, other judicial officers who have a concentration of power in criminal or constitutional proceedings should also not be accountable only to an incumbent president. In these countries, reform to curtail the judicial officers' huge power, or the transfer of control over their careers from the presidency to legislature, is necessarily required. Otherwise, politics may shuttle between the two extremely judicialized circumstances, and therefore political development will be delayed.

\section{Reference}

Bancaud, A., \& Boigeol, A. (1995). A New Judge for a New System of Economic Justice. In Y. Dezalay, \& D. Sugarman (Eds.), Professional Competition and Professional Power: Lawyers, Accountants and the Social Construction of Markets. London: Routledge.

Barzilai, G. (1997). Between the Rule of Law and the Laws of the Ruler. International Social Science Journal, 49(152), 193-208. http://dx.doi.org/10.1111/j.1468-2451.1997.tb00016.x

Bickel, A. (1986). The Least Dangerous Branch: The Supreme Court at the Bar of Politics. New Haven, CT: Yale University Press.

Blondel, J. (1992). Dual Leadership in the Contemporary World. In A. Lijphart (Ed.), Parliamentary versus Presidential Government. Oxford: Oxford University Press.

Caldeira, G. A. (1986). Neither the Purse Nor the Sword: Dynamics of Public Confidence in the Supreme Court. American Political Science Review, 80(4), 1209-1226. Retrieved from http://www.jstor.org/stable/1960864

Carey, J. M. (2005). Presidential versus Parliamentary Government. In C. Ménard, \& M. M. Shirley (Eds.), Handbook of New Institutional Economics. Dordrecht: Springer.

Chavez, R. B., Ferejohn, J. A., \& Weingast B. R. (2003). A Theory of the Politically Independent Judiciary. Paper Prepared for the Annual Meeting of American Political Science Association, Philadelphia.

Chen, L. (2004). Power Plays: Reallocating Power under the New Russian Federation Code of Criminal Procedure. North Carolina Journal of International Law \& Commercial Regulation, 30(2), 429-472. Retrieved from http://www.law.unc.edu/journals/ncilj/issues/volume30/number-2-winter-2004/power-playsreallocating-power-under-the-new-russian-federation-code-of-criminal-procedure/

Cho, S. -S. (2010). Daehanminguk geomchareul malhada 2. Pajoo: Nanam.

Cole, T. (1959). Three Constitutional Courts: A Comparison. American Political Science Review, 53(4), 963-984. Retrieved from http://www.jstor.org/stable/1952070

Crenson, M., \& Ginsberg, B. (2004). Downsizing Democracy. Baltimore, MD: Johns Hopkins University Press.

Dahl, R. A. (1989). Democracy and Its Critics. New Haven, CT: Yale University Press.

della Porta, D. (2001). A Judges' Revolution?: Political Corruption and the Judiciary in Italy. European Journal of Political Research, 39(1), 1-21. http://dx.doi.org/10.1111/1475-6765.00567

Di Federico, G. (1995). Italy: A Peculiar Case. In C. N. Tate, \& T. Vallinder (Eds.), The Global Expansion of Judicial Power. New York: New York University Press.

Di Federico, G. (1998). Prosecutorial Independence and the Democratic Requirement of Accountability in Italy. British Journal of Criminology, 38(3), 371-387. http://bjc.oxfordjournals.org/content/38/3/371

Ehrmann, H. W. (1976). Comparative Legal Cultures. London: Prentice Hall.

Epp, C. R. (1998) Rights Revolution: Lawyers, Activists, and the Supreme Courts in Comparative Perspective. Chicago: University of Chicago Press.

Ferejohn, J., Rosenbluth, F., \& Shipan, C. (2007). Comparative Judicial Politics. In C. Boix, \& S. C. Stokes (Eds.), The Oxford Handbook of Comparative Politics. Oxford: Oxford University Press.

Ferejohn, J. \& Pasquino, P. (2003). Rule of Democracy and Rule of Law. In J. M. Maravall, \& A. Przeworski (Eds.), Democracy and Rule of Law. Cambridge: Cambridge University Press.

Fish, M. S. (2000). The Executive Deception: Superpresidentialism and Degradation of Russian Politics. In V. Sperling (Ed.), Building the Russian State: Institutional Crisis and the Quest for Democratic Governance. Boulder, CO: Westview Press.

Friedman, L. M. (1973). A History of American Law. New York: Simon \& Schuster.

Gargarella, R. (2003). In Search of Democratic Justice - What Courts Should Not Do: Argentina, 1983-2002. 
Democratization, 10(4), 181-198. http://dx.doi.org/10.1080/13510340312331294087

Ginsburg, T. (2003). Judicial Review in New Democracies: Constitutional Courts in Asian Cases. New York: Cambridge University Press.

Ginsburg, T. (2008). Administrative Law and the Judicial Control of Agents in Authoritarian Regimes. In T. Ginsburg, \& T. Moustafa (Eds.), Rule by Law: The Politics of Courts in Authoritarian Regimes. New York: Cambridge University Press.

Grossman, M. B., Kumar, M. J., \& Rourke, F. E. (2000). Second-Term Presidencies: The Aging of Administrations. In M. Nelson (Ed.), The Presidency and the Political System. Washington, DC: CQ Press.

Guarnieri, C. (2003). Courts as an Instrument of Horizontal Accountability: The Case of Latin Europe. In J. M. Maravall, \& A. Przeworski (Eds.), Democracy and the Rule of Law. Cambridge: Cambridge University Press.

Habermas, J. (2001). Constitutional Democracy: A Paradoxical Union of Contradictory Principles. Political Theory, 29(6), 766-781. http://dx.doi.org/10.1177/0090591701029006002

Hamilton, J. (2008). Non-Prosecutorial Functions of the Prosecutors in Common Law Countries. At Conference of Prosecutors General of Europe, The Role of Public Prosecution in the Protection of Human Rights and Public Interests outside the Criminal Law Field. Organised by the Council of Europe and the Prosecutor General's Office of the Russian Federation, St. Petersburg.

Helmke, G. (2002). The Logic of Strategic Defection: Judicial Decision-Making in Argentina under Dictatorship and Democracy. American Political Science Review, 96(2), 291-303. Retrieved from http://www.jstor.org/ stable/3118026

Hirschl, R. (2000). The Political Origins of Judicial Empowerment through Constitutionalization: Lessons from Four Constitutional Revolutions. Law and Social Inquiry, 25(1), 91-148. Retrieved from http://www.jstore.org/stable/829019

Hirschl, R. (2004). Towards Juristocracy: The Origins and Consequences of the New Constitutionalism. Cambridge, MA: Harvard University Press.

Holmes, S. (1999). The Procuracy and Its Problems: Introduction. East European Constitutional Review, 8(1-2), 76-104. Retrieved from http://heinonline.org/HOL/LandingPage?handle=hein.journals/eeurcr8\&div=9\&id= \&page

Jiménez, F. (1998). Political Scandals and Political Responsibility in Democratic Spain. West European Politics, 21(4), 80-99. http://dx.doi.org/10.1080/01402389808425272

Kang, W. (2001). Haengjeong gaehyeokgwa gwallyo jeohang. Hanguksahoewa haengjeong yeongu, 12(3), 3-17. Retrieved from http://www.dbpia.co.kr/Journal/ArticleDetail/653574

Kaufmann, D., \& Siegelbaum, P. (1997). Privatization and Corruption in Transition Economies. Journal of International Affairs, 50(2), 419-458. Retrieved from http://law-journals-books.vlex.com/vid/privatizationcorruption-transition-53699098

Kim, D. -J. (2011). Kim Dae-jung jaseojeon 2. Seoul: Samin.

Kirchheimer, O. (1961). Political Justice: The Use of Legal Procedure for Political Ends. Princeton: Princeton University Press.

Kornhauser, L. A. (2002). Is Judicial Independence a Useful Concept? In S. A. Burbank, \& B. Friedman (Eds.), Judicial Independence at the Crossroads: An Interdisciplinary Approach. Thousand Oaks, CA: Sage.

Kvurt, Y. (2007). Selective Prosecution in Russia: Myth or Reality? Cardozo Journal of International \& Comparative Law, 15(1), 127-168.

Kyprianou, D. (2008). Comparative Analysis of Prosecution Systems (Part II): The Role of Prosecution Services in Investigation and Prosecution Principles and Policies. Cyprus \& European Law Review, 2(7), 1-27.

Larkins, C. M. (1996). Judicial Independence and Democratization: A Theoretical and Conceptual Analysis. American Journal of Comparative Law, 44(4), 605-626. Retrieved from http://www.jstor.org/stable/840623

Lee, H. J. (2007) Geomchare daehan minjujeok tongjewa geomchalgaehyeogui gwaje. Seogangbeopak, 9(2), 43-79. Retrieved from http://www.riss.kr/link?id=A76524578

Lee, S.-W. (2010). To Be or Not to Be: Statism and Paradoxical Evolution of Corporate Governance in Russia. 
Development \& Society, 39(2), 257-285. Retrieved from http://isdpr.org/isdpr/publication/journal/39-2/ 04.pdf

Lijphart, A. (1992). Introduction. In A. Lijphart (Ed.), Parliamentary versus Presidential Government. Oxford: Oxford University Press.

Lijphart, A. (1994). Presidentialism and Majoritarian Democracy: Theoretical Observation. In J. J. Linz, \& A. Valenzuela (Eds.), The Failure of Presidential Democracy. Baltimore, MD: Johns Hopkins University Press.

Linz, J. J. (1994). Presidential or Parliamentary Democracy: Does It Make a Difference? In J. J. Linz, \& A. Valenzuela (Eds.), The Failure of Presidential Democracy. Baltimore, MD: Johns Hopkins University Press.

Magaloni, B. (2008). Enforcing the Autocratic Political Order and the Role of Courts: The Case of Mexico. In T. Ginsburg, \& T. Moustafa (Eds.), Rule by Law: The Politics of Courts in Authoritarian Regimes. New York: Cambridge University Press.

Mainwaring, S. (1993). Presidentialism, Multipartism, and Democracy: The Difficult Combination. Comparative Political Studies, 26(2), 198-228. http://dx.doi.org/10.1177/0010414093026002003

Maravall, J. M. (2003). The Rule of Law as a Political Weapon. In J. M. Maravall, \& A. Przeworski (Eds.), Democracy and the Rule of Law. Cambridge: Cambridge University Press.

Mattei, U., \& Pes, L. G. (2008). Civil Law and Common Law: Toward Convergence. In K. E. Whittington, R. D. Kelemen, \& G. A. Caldeira (Eds.), The Oxford Handbook of Law and Politics. Oxford: Oxford University Press.

Merryman, J. H. (1985). The Civil Law Tradition: An Introduction to the Legal Systems of Western Europe and Latin America. Stanford: Stanford University Press.

North, D. C., \& Weingast, B. R. (1989). Constitutions and Commitment: The Evolution of Institutions Governing Public Choice in Seventeenth Century England. Journal of Economic History, 59(4), 803-832. Retrieved from http://www.jstor.org/stable/2122739

O'Donnell, G. A. (2004). Why the Rule of Law Matters. Journal of Democracy, 15(4), 32-46. http://dx.doi.org/10.1353/jod.2004.0076

Olson, M. (2000). Power and Prosperity: Outgrowing Communist and Capitalist Dictatorships. Oxford: Oxford University Press.

Przeworski, A. (2010). Democracy and the Limits of Self-Government. New York: Cambridge University Press.

Reichel, P. L. (2005). Comparative Criminal Justice Systems: A Topical Approach. Upper Saddle River: Pearson Prentice Hall.

Rose, R. (2009) Democratic and Undemocratic States. In C. Haerpfer, P. Bernhagen, R. F. Inglehart, \& C. Welzel (Eds.), Democratization. Oxford: Oxford University Press.

Russell, P. H. (2001). Toward a General Theory of Judicial Independence. In P. H. Russell, \& D. M. O’Brien (Eds.), Judicial Independence in the Age of Democracy: Critical Perspective from around the World. Charlottesville: University Press of Virginia.

Sartori, G. (1994). Neither Presidentialism nor Parliamentarism. In J. J. Linz, \& A. Valenzuela (Eds.), The Failure of Presidential Democracy. Baltimore, MD: Johns Hopkins University Press.

Sejersted, F. (1988). Democracy and the Rule of Law: Some Historical Experience of Contradictions in the Striving for Good Government. In J. Elster, \& R. Slagstad (Eds.), Constitutionalism and Democracy. Cambridge: Cambridge University Press.

Shapiro, M. (1981). Courts: A Comparative and Political Analysis. Chicago: University of Chicago Press.

Shugart, M. S. (1995). The Electoral Cycle and Institutional Sources of Divided Presidential Government. American Political Science Review, 89(2), 327-343. Retrieved from http://www.jstor.org/stable/2082428

Shugart, M. S., \& Carey, J. M. (1992). Presidents and Assemblies: Constitutional Design and Electoral Dynamics. Cambridge: Cambridge University Press.

Stepan, A., \& Skach, C. (1993). Constitutional Frameworks and Democratic Consolidation: Parliamentarism versus Presidentialism. World Politics, 46(1), 1-22. Retrieved from http://www.jstor.org/stable/2950664 
Stone, S. A. (2000). Governing with Judges: Constitutional Politics in Europe. Oxford: Oxford University Press.

Strøm, K. (2000). Delegation and Accountability in Parliamentary Democracy. European Journal of Political Research, 37(3), 261-289. http://dx.doi.org/10.1111/1475-6765.00513

Tate, C. N., \& Vallinder, T. (1995). The Global Expansion of Judicial Power: The Judicialization of Politics. In C. N. Tate, \& T. Vallinder (Eds.), The Global Expansion of Judicial Power. New York: New York University Press.

The World Justice Project. (2012-2013). The WJP Rule of Law Index. Washington, DC: The World Justice Project.

Valenzuela, A. (1993). Latin America: Presidentialism in Crisis. Journal of Democracy, 4(4), 3-16. http://dx.doi.org/10.1353/jod.1993.0059

Vanberg, G. (2001). Legislative-Judicial Relations: A Game-Theoretic Approach to Constitutional Review. American Political Science Review, 45(2), 346-361. Retrieved from http://www.jstor.org/stable/2669345

Verrest, P. (2000). The French Public Prosecution Service. European Journal of Crime, Criminal Law \& Criminal Justice, 8(3), 210-244. http://dx.doi.org/10.1163/15718170020519166

Weyland, K. (1998). The Politics of Corruption in Latin America. Journal of Democracy, 9(2), 108-121. http://dx.doi.org/10.1353/jod.1998.0034

Zannotti, F. (1995). The Judicialization of Judicial Salary Policy in Italy and the United States. In C. N. Tate, \& T. Vallinder (Eds.), The Global Expansion of Judicial Power. New York: New York University Press.

\section{Copyrights}

Copyright for this article is retained by the author(s), with first publication rights granted to the journal.

This is an open-access article distributed under the terms and conditions of the Creative Commons Attribution license (http://creativecommons.org/licenses/by/3.0/). 